Constructing Uniform Resource Locators (URLs) for Searching the Marine Realms Information Bank

Open-File Report 2009-1266 


\section{Constructing Uniform Resource Locators (URLs) for Searching the Marine Realms Information Bank}

By Guthrie A. Linck, Alan 0. Allwardt, and Frances L. Lightsom

Open-File Report 2009-1266 


\section{U.S. Department of the Interior \\ KEN SALAZAR, Secretary \\ U.S. Geological Survey \\ Marcia K. McNutt, Director}

U.S. Geological Survey, Reston, Virginia: 2009

For more information on the USGS - the Federal source for science about the Earth, its natural and living resources, natural hazards, and the environment, visit http://www.usgs.gov or call 1-888-ASK-USGS

For an overview of USGS information products, including maps, imagery, and publications, visit http://www.usgs.gov/pubprod

To order this and other USGS information products, visit http://store.usgs.gov

Any use of trade, product, or firm names is for descriptive purposes only and does not imply endorsement by the U.S. Government.

Although this report is in the public domain, permission must be secured from the individual copyright owners to reproduce any copyrighted materials contained within this report.

Suggested citation:

Linck, G.A., Allwardt, A.O., and Lightsom, F.L., 2009, Constructing Uniform Resource Locators (URLs) for searching the Marine Realms Information Bank: U.S. Geological Survey Open-File Report 2009-1266, 13 p., available at http://pubs.usgs.gov/of/2009/1266. 


\section{Contents}

Abstract
Introduction
Why Construct Search URLs?

\section{Tables}

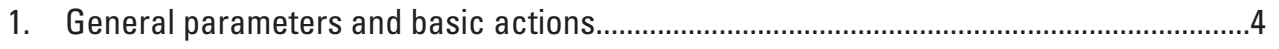

2. Electronic Index Card (EIC) field parameters..................................................................

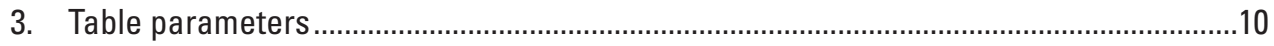

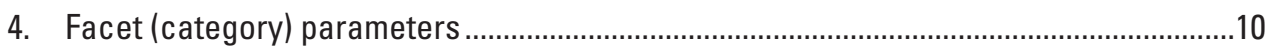

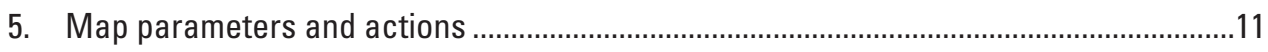




\title{
Constructing Uniform Resource Locators (URLs) for Searching the Marine Realms Information Bank
}

\author{
By Guthrie A. Linck, Alan 0. Allwardt, and Frances L. Lightsom
}

\section{Abstract}

The Marine Realms Information Bank (MRIB) is a digital library that provides access to free online scientific information about the oceans and coastal regions. To search its collection, MRIB uses a Common Gateway Interface (CGI) program, which allows automated search requests using Uniform Resource Locators (URLs). This document provides an overview of how to construct URLs to execute MRIB queries. The parameters listed allow detailed control of which records are retrieved, how they are returned, and how their display is formatted.

\section{Introduction}

The Marine Realms Information Bank (MRIB; http://mrib.usgs.gov) was developed in 2001 by the U.S. Geological Survey (USGS) Coastal and Marine Geology Program (CMGP) in partnership with the Woods Hole Oceanographic Institution (WHOI). The MRIB is a distributed digital geolibrary of worldwide coastal and marine scientific information, created with the desire to provide an alternative to a standard Web search engine. MRIB serves the needs of a diverse audience, including scientists, public servants, advocacy groups, educators, and concerned citizens. For a more complete description of MRIB, see Lightsom and Allwardt (2007; 2009).

The MRIB is an online catalog of Electronic Index Cards (EICs), in which the cards contain many metadata parameters that describe the content of the referenced information resources. Multiple methods of searching for information are offered and are designed to be intuitive and effective in allowing the user to obtain relevant results.

Many of the metadata fields, or facets, provided in the MRIB are hierarchical in nature and indexed using controlled vocabularies of standardized terms; one of these facets is a dictionary of place names, or gazetteer. The MRIB faceted classification provides users with guidance in searching and encourages them to find information using a top-down approach. An analogy that demonstrates the advantage of such a search system would be a sequential key system that guides the user with a series of questions to determine the species of a particular animal instead of having the user type descriptive keywords of the animal into a standard Web search engine. The unguided Web search requires the user to try many combinations of keywords, visit the retrieved Web sites, and wade through irrelevant results. The descriptive keyword approach is inefficient because there are so many ways to describe the same entity. The sequential key, in contrast, is structured to provide guidance and allow the user to more effectively make the determination.

\section{Why Construct Search URLs?}

Knowing how to construct MRIB search URLs and knowing how the search parameters work will allow users to harvest MRIB metadata records without using the online search interface. Automated harvesting could be especially useful to organizations that have compiled their own databases of online scientific information and want to search the MRIB for specific authors or topics. Established databases that overlap in content with MRIB include the Digital Library for Earth System Education (http://www.dlese.org/), the NASA Global Change Master Directory (http://gcmd.nasa.gov/), and the National Science Digital Library (http://nsdl.org/), among others.

Using the EIC modification time parameter (eic.modified, recorded whenever any metadata record is changed), one can search the MRIB for new or corrected records matching certain criteria. A previously harvested record should be checked periodically to see if the corresponding MRIB metadata profile has been modified. For example, if the URL of an online information resource changes because the host institution has restructured its entire URL system, the MRIB metadata profile must be modified to eliminate the dead link. Because distributed digital libraries like MRIB store the URLs of online information resources, not their content, it is essential to maintain valid links to the original resources. 


\section{The MRIB Search URL Structure}

The structure of an MRIB search URL is fairly simple and consists of two parts, separated by a question mark (?). The first part is the URL of the Common Gateway Interface (CGI) program, in this case http://mrib.usgs.gov/ cgi-bin/search. The second part consists of a list of name $=$ value pairs separated by ampersands $(\&)$, which specify the values of the search parameters passed to the CGI program. Thus, to add another search parameter one simply includes the appropriate $\&$ name $=$ value string at the end of the URL.

Accordingly, a simple search request for records matching the single value Environment $>$ Climate Change in the Hot Topics field is executed using this URL: http: / / mrib.usgs.gov/cgi-bin/search?mrib. topics=environment.climate_change.

A more complex example, which includes several search criteria and requests an Extensible Markup Language (XML) export of the retrieved records, is the following: http://mrib.usgs.gov/cgi-bin/ search?mrib.topics=environment. climate change\&mrib.topics=hazards_and_disasters.erosion\&general . author=sallenger, asbury_h.,_jr.\&cmd=ExportCards\&export_ format $=x m l$.

Most non-alphanumeric characters that are passed to the CGI, either in the names or the values, must employ URL encoding, which consists of a percent symbol (\%) followed by the two-digit hexadecimal representation of the special character. URL encoding is discussed in greater detail by Wilson (2003) and by Berners-Lee and others (1994).

\section{What is CGI?}

The Common Gateway Interface (CGI) is a protocol created to provide a standard method of interfacing external programs to an information server in a platform-independent manner. Unlike static HTML Web pages, which are simply retrieved as is, CGI programs are executed dynamically to provide customized content with each invocation. One of the most common types of CGI program is an interactive search service providing access to information from a database server on the Internet. The MRIB falls within this category.

CGI is explained in more detail at a Web site maintained by the National Center for Supercomputing Applications (http://hoohoo.ncsa.illinois.edu/cgi/overview.html). Robinson and Coar (2004) give a technical description of CGI. An excellent source for additional Web-related information is the World Wide Web Consortium (http://www.w3.org/).

\section{Parameter Types}

The MRIB search CGI uses five basic types of parameters. Basic action parameters determine how the results are displayed or used; an example would be $\mathrm{cmd}=\mathrm{Vi}$ iewMap, which displays search results on a geographical map. Electronic Index Card (EIC) field parameters are used to limit the search to those records that match specified values in certain fields; an example would be general.title=seafloor, which will match records with the string "seafloor" in the title. Table parameters determine how the table of search results is displayed and used; an example would be rows $=50$ to display 50 records per page in a table of search results. Map parameters determine the appearance of the map and how search results are depicted on it; an example would be proj=m, which employs the Mercator projection for the map display. Finally, facet parameters determine how the MRIB facets indexing categories are displayed to guide a topical search; an example would be maxdepth $=2$, which displays the first three levels in a facet hierarchy.

\section{Tables of Parameters}

The following tables list all search URL parameters that can be passed to the basic MRIB search CGI (http: / / mrib.usgs.gov/cgi-bin/search) to refine a specific search request. The parameter tables below are organized into three columns.

Parameter: Name of the parameter, as well as any synonyms. The first parameter name (in bold) is the primary name used in the underlying code. The synonyms are provided for ease of use; some are former names from previous versions of MRIB.

Arguments: Number of values that may be specified for each parameter. Parameters with 1 in the Arguments column accept only one value; parameters with an asterisk in the Arguments column accept multiple values. The single-value parameters may be specified multiple times in the URL, but only one value will be recognized (usually the last value, but the order in which they are passed to the MRIB search CGI will be browser dependent, and therefore not well defined).

Description: How the parameter functions.

The five tables include parameters that govern different functions of the MRIB search. 
1. General parameters and basic actions (table 1) determine which of several basic MRIB Web pages are generated to guide the search and report the results: facet (category) view, for topical searches; map view, for geographic searches; table view, for viewing and sorting the search results; and export view, for harvesting MRIB records.

2. Electronic Index Card (EIC) field parameters (table 2) correspond to the EIC metadata fields and determine which MRIB records are selected by the search.

3. Table parameters (table 3 ) determine the format of a Web page that displays a table of search results: records per page, sort field, sort order, and so on.

4. Facet (category) parameters (table 4) determine the format of a Web page that lists the controlled vocabulary of a selected facet (indexing category): for example, the depth of the hierarchy to be displayed.

5. Map parameters and actions (table 5) determine the appearance of a Web page that displays search results on a map: bounding coordinates, scale, representation of relief, resolution, and so on.

\section{References Cited}

Berners-Lee, T., Masinter, L., and McCahill, M., eds., 1994, Uniform Resource Locators (URL), Internet Engineering Task Force RFC 1738, available at http://www.ietf.org/rfc/ rfc1738.txt.

Lightsom, F.L., and Allwardt, A.O., 2007, The Marine Realms Information Bank family of digital libraries-Access to free online information for coastal and marine science: U.S. Geological Survey Fact Sheet 2007-3025, 2 p., available at http://pubs.usgs.gov/fs/2007/3025/.

Lightsom, F.L., and Allwardt, A.O., 2009, USGS digital libraries for coastal and marine science, in Theng, Y.-L., and others, eds., Handbook of research on digital librariesDesign, development, and impact: Hershey, Pa., Information Science Reference, p. 421-430, available at http://mrib.usgs.gov/doc/handbook.pdf.

Robinson, D., and Coar, K., 2004, The Common Gateway Interface (CGI) Version 1.1: Internet Engineering Task Force RFC 3875, available at $h t t p: / / w w w . i e t f . o r g / r f c /$ rfc3875.txt.

Wilson, Brian, 2003, URL encoding (or: 'What are those "\%20" codes in URLs?'), available at http://www.blooberry. com/indexdot/html/topics/urlencoding.htm. 
Table 1. General parameters and basic actions.

\begin{tabular}{|c|c|c|}
\hline Parameter & Arguments & Description \\
\hline $\begin{array}{l}\text { cmd, } \\
\text { action, } \\
\text { a }\end{array}$ & 1 & $\begin{array}{l}\text { Specifies the action to take after the search has been performed. All valid actions begin with a capital } \\
\text { letter, including basic actions such as ViewTable, ViewMap, ViewFacet, and ExportCards (below) } \\
\text { and map actions such as ZoomIn, ZoomOut, and ZoomReset (table 5). Actions can be specified using } \\
\text { the } c m \text { d parameter (for example, cmd=ViewTable) or by passing the action directly (for example, } \\
\text { ViewTable=1). In the second instance, the action accepts Boolean }(1 / 0) \text { values: if the value is } 0 \\
\text { (or an empty string), then the parameter will be ignored; if the value is } 1 \text {, then the action will be taken. } \\
\text { Some action parameters, such as Compass and Imap (table 5), also have P.x and P.y counterparts to } \\
\text { work with image maps. }\end{array}$ \\
\hline NewSearch & 1 & Returns to the search home page. Accepts Boolean $(1 / 0)$ values. \\
\hline ViewTable & 1 & Displays the current search results in a table. Accepts Boolean $(1 / 0)$ values. \\
\hline ViewMap & 1 & Displays the current search results on a map. Accepts Boolean $(1 / 0)$ values. \\
\hline ViewFacet & 1 & $\begin{array}{l}\text { Displays the current search results in the context of a selected facet (indexing category). Accepts Boolean } \\
(1 / 0) \text { values. Used in conjuction with the facet parameter. }\end{array}$ \\
\hline $\begin{array}{l}\text { ViewSelections, } \\
\text { ViewCards }\end{array}$ & 1 & $\begin{array}{l}\text { Used in conjunction with the idlist parameter to select and display individual records from a previously } \\
\text { generated table of search results. Accepts Boolean }(1 / 0) \text { values. }\end{array}$ \\
\hline $\begin{array}{l}\text { RemoveSelections, } \\
\text { RemoveCards }\end{array}$ & 1 & $\begin{array}{l}\text { Used in conjunction with the } i d l i s t \_x \text { parameter to remove individual records from a previously gener- } \\
\text { ated table of selections. Accepts Boolean }(1 / 0) \text { values. }\end{array}$ \\
\hline ContinueSearch & 1 & $\begin{array}{l}\text { Returns the user from a table of selections to the original table of search results. Accepts Boolean }(1 / 0) \\
\text { values. }\end{array}$ \\
\hline user & 1 & $\begin{array}{l}\text { Parameter specifying the user interface to display. Three values are currently recognized: mrib for the } \\
\text { Marine Realms Information Bank (the default); cch for the Coastal Change Hazards Digital Library; } \\
\text { and mbs for the Monterey Bay Science Digital Library. }\end{array}$ \\
\hline
\end{tabular}


Table 2. Electronic Index Card (EIC) field parameters.

\begin{tabular}{|c|c|c|}
\hline Parameter & Arguments & Description \\
\hline $\begin{array}{l}\text { eic.id, } \\
\text { id }\end{array}$ & 1 & $\begin{array}{l}\text { Unique, eight-character hexadecimal identifier assigned by the MRIB Administrator to } \\
\text { each EIC (record) in an MRIB top-level directory. All EICs matching the specified } \\
\text { ID number or partial ID number are retrieved (matched left to right if fewer than } \\
\text { eight characters are specified). Basic searches retrieve EICs from /mrib (the default } \\
\text { top-level directory), unless a different top-level directory is specified (see eic.file). }\end{array}$ \\
\hline $\begin{array}{l}\text { eic.file, } \\
\text { file }\end{array}$ & 1 & $\begin{array}{l}\text { Specifies the nested directory and file structure in which an EIC is stored. The top-level } \\
\text { directories include / mrib (the publicly available database), / contrib (user- } \\
\text { contributed EICs), and individual user accounts (provisional EICs). This parameter } \\
\text { limits the search to records in the given directory or file. For example, most of the re- } \\
\text { cords found in the Coastal Change Hazards Digital Library are stored in the mrib/ } \\
\text { cch directory. }\end{array}$ \\
\hline
\end{tabular}

\begin{tabular}{|c|c|c|}
\hline $\begin{array}{l}\text { eic.type, } \\
\text { type }\end{array}$ & 1 & $\begin{array}{l}\text { Specifies the type of record to be searched: single documents ( } 0 \mid \text { item) or collections } \\
(1 \mid \text { collection), reflecting the nature of the referenced information resources. }\end{array}$ \\
\hline eic.collection & 1 & $\begin{array}{l}\text { Not currently utilized as an indexing parameter. The default value for collection records } \\
\text { is eic.collection=* (see also eic.type). }\end{array}$ \\
\hline $\begin{array}{l}\text { eic.public_id, } \\
\text { eic.pid, } \\
\text { pid, } \\
\text { public_id }\end{array}$ & 1 & $\begin{array}{l}\text { Assigned by the MRIB Administrator to track user-contributed EICs that have been } \\
\text { incorporated into the publicly available database. The public database IDs shown in } \\
\text { the / contrib directory correspond to the EIC IDs in the / mrib directory. Search } \\
\text { is performed in the same way as in the eic.id field. }\end{array}$ \\
\hline $\begin{array}{l}\text { eic.accession_id, } \\
\text { eic.submission_id, } \\
\text { eic.sid, } \\
\text { eic.submit_id, } \\
\text { sid, } \\
\text { submission_id, } \\
\text { submit_id }\end{array}$ & 1 & $\begin{array}{l}\text { Assigned by the MRIB Administrator to track provisional, user-contributed EICs await- } \\
\text { ing review. The Accession IDs shown in the /mrib directory correspond to the } \\
\text { EIC IDs in the / contrib directory. Search is performed in the same way as in the } \\
\text { eic.id field. }\end{array}$ \\
\hline $\begin{array}{l}\text { eic.modified, } \\
\text { eic.mtime }\end{array}$ & 1 & $\begin{array}{l}\text { Date the EIC was last modified. See date formats. }{ }^{1} \text { Prefix with }<\text { to search for records } \\
\text { modified before the specified date or with }>\text { to search for records modified after the } \\
\text { specified date. }\end{array}$ \\
\hline $\begin{array}{l}\text { eic.submitted, } \\
\text { eic.stime }\end{array}$ & 1 & $\begin{array}{l}\text { Date the EIC was submitted to the MRIB Administrator for review and incorporation } \\
\text { into the publicly available database. See date formats. }{ }^{1} \text { Prefix with }<\text { to search for } \\
\text { records submitted before the specified date or with }>\text { to search for records submitted } \\
\text { after the specified date. }\end{array}$ \\
\hline $\begin{array}{l}\text { eic.indexer, } \\
\text { indexer }\end{array}$ & $*$ & $\begin{array}{l}\text { The name and email address of the person who created or modified the EIC. Stored val- } \\
\text { ues are in the format Last, First_Middle namedemail.com (the middle } \\
\text { name or initial and email address are optional). Search is performed using simple } \\
\text { string matching. }{ }^{2}\end{array}$ \\
\hline eic.rules & 1 & $\begin{array}{l}\text { Limits the search to records created under a specific set of cataloging rules. At present, } \\
\text { two sets of rules are recognized: mrib, which employs the generalized Hot Topics } \\
\text { controlled vocabulary (the default), and cch, which employs the specialized Coastal } \\
\text { Change Hazards Topics }{ }^{3} \text { controlled vocabulary. Search is performed using simple } \\
\text { string matching. }\end{array}$ \\
\hline $\begin{array}{l}\text { general.url, } \\
\text { url }\end{array}$ & 1 & $\begin{array}{l}\text { Uniform Resource Locator (URL) for the referenced information resource. Search is } \\
\text { performed using simple string matching. }{ }^{2}\end{array}$ \\
\hline
\end{tabular}


Table 2. Electronic Index Card (EIC) field parameters. - Continued

\begin{tabular}{|c|c|c|}
\hline Parameter & Arguments & Description \\
\hline $\begin{array}{l}\text { eic.url_active, } \\
\text { url_active }\end{array}$ & 1 & $\begin{array}{l}\text { Indicates the status of the URL for the referenced information resource: active (0) or } \\
\text { not active (1). This database management parameter is not currently utilized. }\end{array}$ \\
\hline $\begin{array}{l}\text { general.custodian, } \\
\text { general.curator, } \\
\text { general.poc, } \\
\text { custodian, } \\
\text { curator, } \\
\text { poc }\end{array}$ & $*$ & $\begin{array}{l}\text { The name and email address of the person responsible for providing the information } \\
\text { resource on a Web site (and who normally responds to inquiries about this Web site } \\
\text { and its content). Stored values are in the format Last,_First_Middle namee } \\
\text { email.com (the middle name or initial and email address are optional). A custodial } \\
\text { title (for example, Agency_Webmaster) may be listed in place of a personal } \\
\text { name. The URL of a "Contact Webmaster" Web form may be substituted for the } \\
\text { email address. Search is performed using simple string matching. }\end{array}$ \\
\hline $\begin{array}{l}\text { general.description, } \\
\text { general.desc, } \\
\text { description, } \\
\text { desc }\end{array}$ & 1 & $\begin{array}{l}\text { Basic description of the content of the referenced information resource. Search is } \\
\text { performed using simple string matching. }{ }^{2}\end{array}$ \\
\hline $\begin{array}{l}\text { general.content_start_date, } \\
\text { general.content_start, } \\
\text { general.content_begin_date, } \\
\text { general.content_begin, } \\
\text { content_start_date, } \\
\text { content_start, } \\
\text { content_begin_date, } \\
\text { content_begin }\end{array}$ & 1 & $\begin{array}{l}\text { Starting date (and time, if applicable) of the intellectual content in the information } \\
\text { resource. See date formats. }{ }^{1} \text { Prefix with }<\text { to search for content starting before the } \\
\text { specified date or with }>\text { to search for content starting after the specified date. }\end{array}$ \\
\hline $\begin{array}{l}\text { general.mean_latitude, } \\
\text { general.mean_lat, } \\
\text { general.latitude, } \\
\text { general.lat, } \\
\text { mean_latitude, } \\
\text { mean_lat, } \\
\text { latitude, } \\
\text { lat }\end{array}$ & 1 & $\begin{array}{l}\text { Mean latitude of the study area referenced in the information resource (if applicable). } \\
\text { This field is not currently implemented as a search parameter. }\end{array}$ \\
\hline
\end{tabular}


Table 2. Electronic Index Card (EIC) field parameters.-Continued

\begin{tabular}{|c|c|c|}
\hline Parameter & Arguments & Description \\
\hline $\begin{array}{l}\text { general.west_longitude, } \\
\text { general.west_lon, } \\
\text { west_longitude, } \\
\text { west_lon, } \\
\text { x0 }\end{array}$ & 1 & $\begin{array}{l}\text { West bounding coordinate of the study area referenced in the information resource } \\
\text { (if applicable). See degree formats. }{ }^{4} \text { Note: geographic searches are usually specified } \\
\text { using mrib.location or the zoom parameter. }\end{array}$ \\
\hline $\begin{array}{l}\text { general.east_longitude, } \\
\text { general.east_lon, } \\
\text { east_longitude, } \\
\text { east_lon, } \\
\text { x1 }\end{array}$ & 1 & $\begin{array}{l}\text { East bounding coordinate of the study area referenced in the information resource } \\
\text { (if applicable). See degree formats. }{ }^{4} \text { Note: geographic searches are usually specified } \\
\text { using mrib.location or the zoom parameter. }\end{array}$ \\
\hline $\begin{array}{l}\text { general.north_latitude, } \\
\text { general.north_lat, } \\
\text { north_latitude, } \\
\text { north_lat, } \\
\text { y1 }\end{array}$ & 1 & $\begin{array}{l}\text { North bounding coordinate of the study area referenced in the information resource } \\
\text { (if applicable). See degree formats. }{ }^{4} \text { Note: geographic searches are usually specified } \\
\text { using mrib.location or the zoom parameter. }\end{array}$ \\
\hline $\begin{array}{l}\text { general.mean_elevation, } \\
\text { general.mean_elev, } \\
\text { general.elev, } \\
\text { mean_elev, } \\
\text { mean_elevation, } \\
\text { elev }\end{array}$ & 1 & $\begin{array}{l}\text { Mean elevation (in meters) of the study area described in the referenced information } \\
\text { resource (if applicable). Prefix with }<\text { to search for elevations below the specified } \\
\text { value or with }>\text { to search for elevations above the specified value. }\end{array}$ \\
\hline $\begin{array}{l}\text { general.keywords, } \\
\text { keywords, } \\
\text { keyword }\end{array}$ & $*$ & $\begin{array}{l}\text { Searches both the controlled-vocabulary terms (see below) and free-text keywords that } \\
\text { were used to index the information resource. Search is performed using simple string } \\
\text { matching. }{ }^{2}\end{array}$ \\
\hline $\begin{array}{l}\text { general.author, } \\
\text { author }\end{array}$ & $*$ & $\begin{array}{l}\text { Limits search to records matching one or more of the specified authors (persons respon- } \\
\text { sible for the intellectual content of the information resource). See the list of regis- } \\
\text { tered Authors. }{ }^{3} \text { Note that MRIB does not employ "corporate authors" (this informa- } \\
\text { tion is conveyed in the Agency field). }\end{array}$ \\
\hline $\begin{array}{l}\text { mrib.agency, } \\
\text { agency }\end{array}$ & $*$ & $\begin{array}{l}\text { Limits search to records matching one or more of the specified agencies (organizations } \\
\text { that contributed to the information resource, by funding or conducting research, } \\
\text { interpreting or compiling data, publishing a document, hosting a Web site, and so } \\
\text { on.). See the list of registered Agencies. }\end{array}$ \\
\hline $\begin{array}{l}\text { mrib.discipline, } \\
\text { discipline }\end{array}$ & $*$ & $\begin{array}{l}\text { Limits search to records matching one or more of the specified disciplines (academic } \\
\text { fields relevant to the scientific research or issues discussed in the information } \\
\text { resource). See the list of registered Disciplines. }\end{array}$ \\
\hline $\begin{array}{l}\text { mrib.location, } \\
\text { loc, } \\
\text { location }\end{array}$ & 1 & $\begin{array}{l}\text { Limits search to records matching the specified gazetteer location. See the list of } \\
\text { registered Gazetteer Locations. }{ }^{3}\end{array}$ \\
\hline
\end{tabular}


Table 2. Electronic Index Card (EIC) field parameters. - Continued

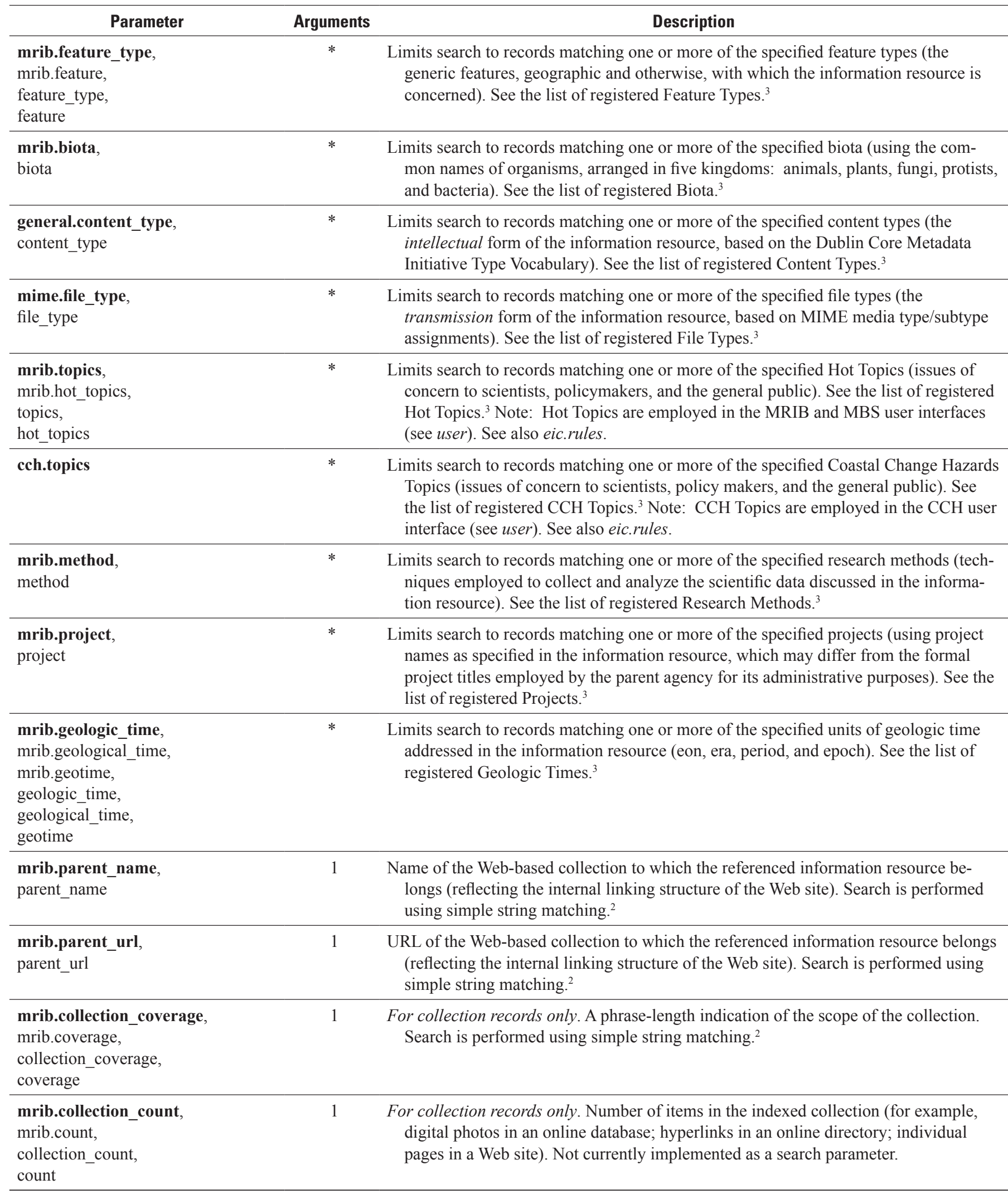


Table 2. Electronic Index Card (EIC) field parameters.-Continued

\begin{tabular}{|c|c|c|}
\hline Parameter & Arguments & Description \\
\hline $\begin{array}{l}\text { mrib.collection_update_frequency, } \\
\text { mrib.update_frequency, } \\
\text { mrib.update, } \\
\text { collection_update_frequency, } \\
\text { update_frequency, } \\
\text { update }\end{array}$ & $*$ & $\begin{array}{l}\text { For collection records only. Limits search to records matching one or more of the spec- } \\
\text { ified collection update frequencies. See the list of registered Update Frequencies. }\end{array}$ \\
\hline $\begin{array}{l}\text { mrib.subset, } \\
\text { subset }\end{array}$ & $*$ & $\begin{array}{l}\text { Limits the search to records assigned by the indexer to one or more subsets of the } \\
\text { MRIB database. The MRIB database currently includes two subsets: Coastal_- } \\
\text { Change_Hazards (displayed in the Coastal Change Hazards Digital Library) and } \\
\text { Monterey_Bay_Science (displayed in the Monterey Bay Science Digital } \\
\text { Library). }\end{array}$ \\
\hline
\end{tabular}

${ }^{1}$ Dates and times use the format yyyy/mm/dd $\mathrm{hh}: \mathrm{mm}: \mathrm{ss}$ (mm/dd and $\mathrm{hh}: \mathrm{mm}$ : ss are optional). Times follow the 24-hour clock convention. For sorting purposes, a less specific date (for example, 1999) predates a more specific date (for example, 1999/5).

${ }^{2}$ MRIB uses simple case-insensitive substring matching. Search values beginning with a forward slash (/) are interpreted as Perl regular expressions, allowing the experienced programmer to construct complex queries using Boolean and comparison operators. See the Perl Regular Expressions Tutorial (http://perldoc.perl.org/perlretut.html) and examples from the MRIB Advanced Search Form (http://mrib.usgs.gov/cgi-bin/search?advanced=1\#Examples).

${ }^{3}$ The MRIB controlled vocabulary is online at http://mrib.usgs.gov/doc/facets.html.

${ }^{4}$ Geographic coordinates are stored internally as decimal degrees (dd. ddd) but also may be specified in degrees, minutes, and seconds (dd: mm: s. ). Longitude values may be expressed in three formats: -180 to $180,180 \mathrm{~W}$ to $180 \mathrm{E}$, or 0 to 360 . Latitude values may be expressed in two formats: -90 to 90 or $90 \mathrm{~S}$ to $90 \mathrm{~N}$.

${ }^{5}$ The list of update frequencies is online at http://mrib.usgs.gov/meta/collection_update_frequency.html. 
Table 3. Table parameters.

\begin{tabular}{|c|c|c|}
\hline Parameter & Arguments & Description \\
\hline $\begin{array}{l}\text { stop, } \\
\text { stoprec }\end{array}$ & 1 & $\begin{array}{l}\text { In a sequential table of search results, the stop parameter specifies the last record to be displayed in the } \\
\text { table. }\end{array}$ \\
\hline page & 1 & $\begin{array}{l}\text { In a multipage table of search results, the page parameter specifies the first page to be displayed. The default } \\
\text { setting is page }=0 \text {, which displays page } 1 \text { first. (The records included on the first page to be displayed } \\
\text { will also depend on the rows parameter. Example: page }=1 \text { and rows }=10 \text { will display page } 2 \text { first, with } \\
\text { records } 11-20 \text {.) }\end{array}$ \\
\hline $\begin{array}{l}\text { sort, } \\
\text { sortfield, } \\
\text { sort_field }\end{array}$ & 1 & $\begin{array}{l}\text { Specifies the field used to sort a table of search results. The default field for sorting is general.author, but } \\
\text { any other field in the table may be used: eic.type, general.title, or general.date. Search results may also } \\
\text { be sorted by fields not normally shown in the table, such as eic.id, general.content_start_date, and } \\
\text { general.content_end_date. }\end{array}$ \\
\hline $\begin{array}{l}\text { idlist, } \\
\text { id_list }\end{array}$ & $*$ & $\begin{array}{l}\text { Parameter used in conjunction with ViewSelections to select and display individual records from a previ- } \\
\text { ously generated table of search results. Multiple instances of this parameter may be passed. The format is } \\
\text { hexadecimal (see eic.id). }\end{array}$ \\
\hline $\begin{array}{l}\text { idlist_x, } \\
\text { id_list_x, } \\
\text { id_x }\end{array}$ & $*$ & $\begin{array}{l}\text { Parameter used in conjunction with RemoveSelections to remove individual records from a previously gen- } \\
\text { erated table of selections. Multiple instances of this parameter may be passed. The format is hexadecimal } \\
\text { (see eic.id). }\end{array}$ \\
\hline $\begin{array}{l}\text { export_format, } \\
\text { export_fmt, } \\
\text { export }\end{array}$ & 1 & $\begin{array}{l}\text { Parameter used in conjunction with ExportCards to specify the format of exported search results. The avail- } \\
\text { able export formats }{ }^{1} \text { include plain text }(\mathrm{txt}) \text {, comma-separated values ( } \mathrm{csv} \text { or } \mathrm{CSV} \text { int), Extensible } \\
\text { Markup Language (xml), Keyhole Markup Language }(\mathrm{kml}) \text {, and Electronic Index Card format (eic_ } \\
\text { mod). The latter is the internal format used to store records in the MRIB database. }\end{array}$ \\
\hline
\end{tabular}

${ }^{1}$ MRIB export formats are described in more detail at $h t t p: / / m r i b . u s g s . g o v / d o c / e x p o r t . h t m l$.

Table 4. Facet (category) parameters.

\begin{tabular}{lcr}
\hline \multicolumn{1}{c}{ Parameter } & Arguments & \multicolumn{1}{c}{ Description } \\
\hline $\begin{array}{l}\text { facet, } \\
\text { f, } \\
\text { category }\end{array}$ & 1 & $\begin{array}{r}\text { Specifies the facet to search. Used in conjunction with the facet_value parameter and any basic action } \\
\text { (ViewTable, ViewMap, ViewFacet, or ExportCards). }\end{array}$ \\
\hline $\begin{array}{l}\text { facet_value, } \\
\text { fvalue, } \\
\text { fv, } \\
\text { category_value }\end{array}$ & 1 & $\begin{array}{r}\text { Used in conjunction with the facet parameter to specifiy a particular facet value. Facet values may be speci- } \\
\text { fied by name, ID, or ID span (for example, see Agency facet: http://mrib.usgs.gov/meta/agency.html). }\end{array}$ \\
$\begin{array}{l}\text { maxdepth, } \\
\text { depth, } \\
\text { level }\end{array}$ & 1 & $\begin{array}{r}\text { Used in conjunction with the facet parameter and ViewFacet to specify the number of levels to display in a } \\
\text { facet hierarchy. The default display is two levels (maxdepth=1). }\end{array}$ \\
\hline
\end{tabular}


Table 5. Map parameters and actions.

\begin{tabular}{|c|c|c|}
\hline Parameter & Arguments & Description \\
\hline geosearch & 1 & $\begin{array}{l}\text { Specifies how geographic searches are performed: } 0 \text { | mean (the default) finds study areas whose } \\
\text { center points (mean latitude and longitude) are located in the current map region; } 1 \text { | within } \\
\text { finds study areas that fall entirely within the current map region; } 2 \text { | contains finds study } \\
\text { areas that completely encompass the current map region; } 3 \text { I intersects finds study areas that } \\
\text { intersect the current map region. }\end{array}$ \\
\hline imap_action & 1 & $\begin{array}{l}\text { Specifies the action taken when clicking on the map: } 0 \mid \text { ZoomIn (the default) zooms in on the } \\
\text { click point; } 1 \mid \text { auto either selects a table of search results or zooms in, depending on the density } \\
\text { of search results at the click point; } 2 \mid \text { select } \mid \text { table selects a table of search results for the } \\
\text { click point; } 3 \mid \text { ZoomOut zooms out from the click point; } 4 \mid \text { pan } \mid \text { center recenters the map on } \\
\text { the click point. }\end{array}$ \\
\hline zoom & 1 & $\begin{array}{l}\text { Limits the search to the specified geographic bounding box. The format is } \mathrm{W} / \mathrm{E} / \mathrm{S} / \mathrm{N} \text {, with coordi- } \\
\text { nates expressed either in decimal degrees or in degrees, minutes, and seconds (see deg_format). } \\
\text { Note: the four bounding parameters that define a specific study area may also be searched: } \\
\text { see general.west_longitude, general.east_longitude, general.north_latitude, and } \\
\text { general.south_latitude. }\end{array}$ \\
\hline $\begin{array}{l}\text { scale, } \\
\text { map_scale }\end{array}$ & 1 & A relative scale from 3 (narrow) to 20 (wide), with 6 being the default setting. \\
\hline $\begin{array}{l}\text { proj, } \\
\text { projection, } \\
\text { map_projection }\end{array}$ & 1 & $\begin{array}{l}\text { The following Generic Mapping Tools (GMT) map projections }{ }^{1} \text { are currently supported: Mercator } \\
(\mathrm{m}) \text {, basic cylindrical }(\mathrm{y}) \text {, equidistant cylindrical }(\mathrm{q}) \text {, and polar }(\mathrm{p}) \text {. }\end{array}$ \\
\hline pproj & 1 & $\begin{array}{l}\text { Internal field containing information about the previous map, used to determine how to generate the } \\
\text { next map. The format is } \mathrm{PM} / \mathrm{S} \text {, where } \mathrm{P} \text { is the projection, } \mathrm{M} \text { is the median longitude (in } 0-360 \\
\text { degree format), and } \mathrm{S} \text { is the scale. }\end{array}$ \\
\hline $\begin{array}{l}\text { res, } \\
\text { resolution, } \\
\text { map_resolution }\end{array}$ & 1 & $\begin{array}{l}\text { Specifies the resolution of physical features on shaded relief maps (not applicable to outline maps). } \\
\text { The five GMT resolutions }{ }^{1} \text { are } \mathrm{f}|\mathrm{full}, \mathrm{h}| \mathrm{h} \text { igh, } \mathrm{m} \mid \text { medium, } \mathrm{l} \mid \mathrm{low} \text {, and } \mathrm{c} \mid \mathrm{crude} \text {. The } \\
\text { default resolution is } \mathrm{m} \mid \text { medium. Higher resolution maps take longer to generate. }\end{array}$ \\
\hline deg_format & 1 & $\begin{array}{l}\text { Specifies the format of latitude and longitude values. To display degrees, minutes, and seconds (the } \\
\text { default setting in the MRIB map interface), use deg_format=dd:mm: s. To display decimal } \\
\text { degrees, use deg_format }=\mathrm{dd} \text {. ddd (three decimal places being the practical limit). Either } \\
\text { format may also accept a plus sign (encoded as } \circ 2 \mathrm{~B} \text { ) as the leading character, in which case the } \\
\text { following conventions will be employed: }-90 \text { to } 90 \text { for latitude and } 0 \text { to } 360 \text { for longitude. }\end{array}$ \\
\hline $\begin{array}{l}\text { dpi, } \\
\text { dots_per_inch }\end{array}$ & 1 & $\begin{array}{l}\text { Specifies the dots per inch when generating map images. A larger } d p i \text { value will produce a higher } \\
\text { resolution image, but the map will also take longer to generate. The default setting is dp } i=200 \text {. }\end{array}$ \\
\hline $\begin{array}{l}\text { image_type, } \\
\text { img_type, } \\
\text { img }\end{array}$ & 1 & $\begin{array}{l}\text { Specifies the image format for generating maps: JPEG | JPG, PNG, or GIF. The default image } \\
\text { format is JPEG. }\end{array}$ \\
\hline $\mathbf{x y}$ & 1 & $\begin{array}{l}\text { Internally used field specifying the width and height of the previous map image, in pixels (for } \\
\text { example, } x y=540 \times 320 \text { ). }\end{array}$ \\
\hline area & 1 & $\begin{array}{l}\text { Specifies the bounding coordinates of the map display. The format is } \mathrm{W} / \mathrm{E} / \mathrm{S} / \mathrm{N} \text { (see also } \\
\text { deg_format). The area parameter overrides the zoom parameter in order to change the map } \\
\text { display without changing the search coordinates. }\end{array}$ \\
\hline
\end{tabular}


Table 5. Map parameters and actions.-Continued

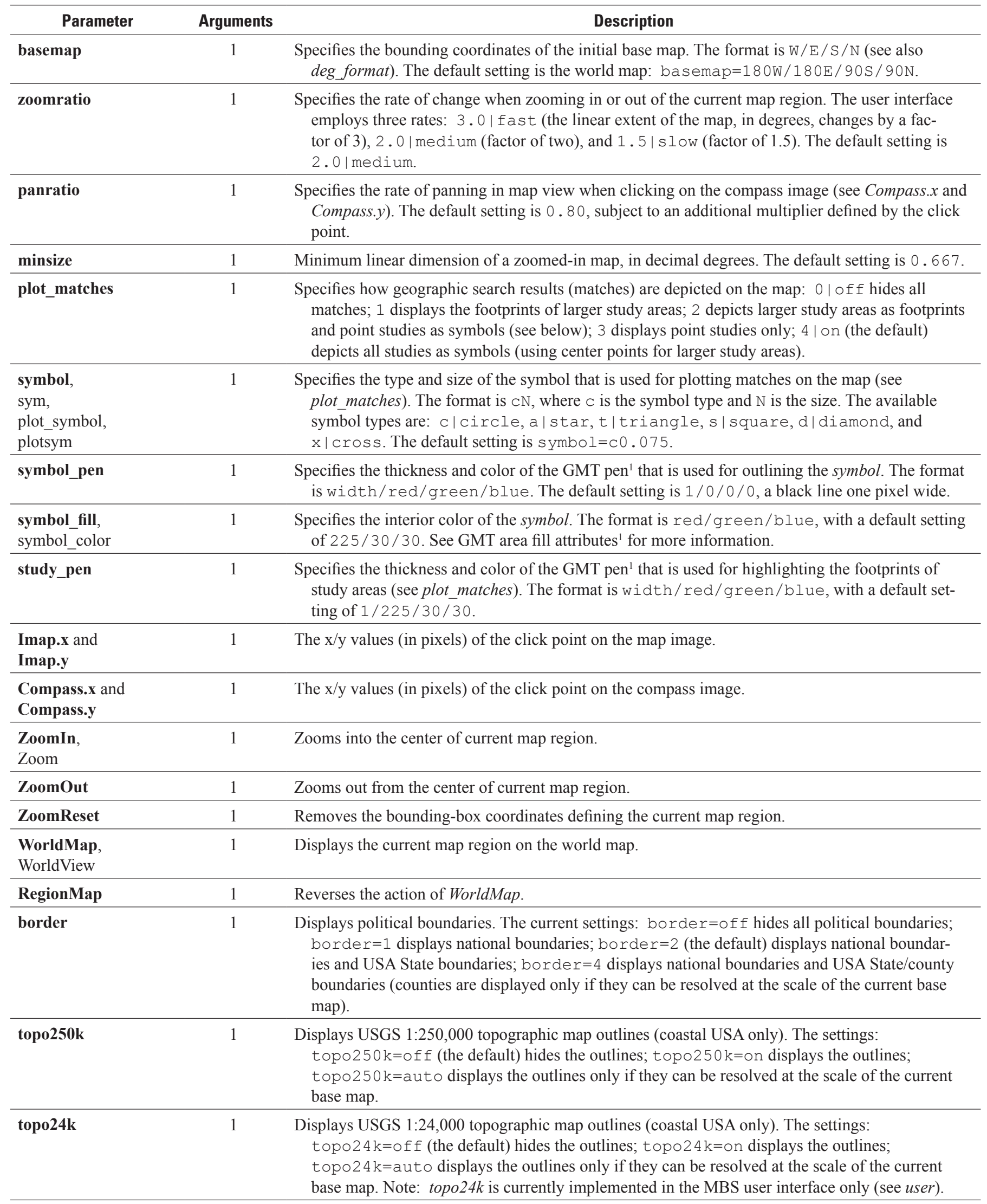


Table 5. Map parameters and actions.-Continued

\begin{tabular}{|c|c|c|}
\hline Parameter & Arguments & Description \\
\hline eez & 1 & $\begin{array}{l}\text { Displays Exclusive Economic Zone boundaries (USA only). The settings: ee } z=\circ f f \text { (the default) } \\
\text { hides the boundaries; eez=on displays the boundaries; ee } z=a u t o \text { displays the boundaries only } \\
\text { if they can be resolved at the scale of the current base map. }\end{array}$ \\
\hline nms & 1 & $\begin{array}{l}\text { Displays National Marine Sanctuary and Marine National Monument boundaries (USA only). } \\
\text { The settings: nms=off (the default) hides the boundaries; nms }=\text { on displays the boundaries; } \\
\text { nms=auto displays the boundaries only if they can be resolved at the scale of the current base } \\
\text { map. }\end{array}$ \\
\hline opdlm & 1 & $\begin{array}{l}\text { Displays Minerals Management Service (MMS) Official Protraction Diagram and Leasing Map } \\
\text { outlines (offshore USA only). The settings: opdlm=off (the default) hides the outlines; } \\
\text { opdlm=on displays the outlines; opdlm=auto displays the outlines only if they can be re- } \\
\text { solved at the scale of the current base map. }\end{array}$ \\
\hline hucs & 1 & $\begin{array}{l}\text { Displays USGS hydrologic unit (watershed) boundaries (USA only). The settings: huc=off (the } \\
\text { default) hides the boundaries; huc=on displays the boundaries; huc=auto displays the bound- } \\
\text { aries only if they can be resolved at the scale of the current base map. }\end{array}$ \\
\hline river & 1 & $\begin{array}{l}\text { Displays rivers. The settings: river=off (the default) hides rivers; river=on displays rivers; } \\
\text { river=auto displays rivers only if they can be resolved at the scale of the current base map. }\end{array}$ \\
\hline lake & 1 & $\begin{array}{l}\text { Displays lakes. The settings: lake=of } \mathrm{f} \text { hides lakes; la ke=on displays lakes; lake=auto (the } \\
\text { default) displays lakes only if they can be resolved at the scale of the current base map. }\end{array}$ \\
\hline
\end{tabular}

\footnotetext{
${ }^{1}$ For more information about Generic Mapping Tools (GMT) map parameters, see http://gmt.soest.hawaii.edu/gmt/doc/gmt/html/GMT_Docs/node1.html.
} 
Prepared by the Pembroke Publishing Service Center.

For more information concerning this report, contact:

Director

U.S. Geological Survey

Woods Hole Coastal and Marine Science Center

384 Woods Hole Road

Quissett Campus

Woods Hole, MA 02543-1598

wbarnhardt@usgs.gov

508-548-8700 or 508-457-2200

or visit our Web site at:

http://woodshole.er.usgs.gov/ 
